\title{
FACTORS INFLUENCING THE USE OF LONG-LASTING CONTRACEPTION METHODS AMONG REPRODUCTIVE-AGE WOMEN IN SUKMAJAYA COMMUNITY HEALTH CARE, DEPOK, WEST JAVA
}

\author{
Nancy Dalla Darsono, Sri Wahyuningsih, Agneta Irmarahayu \\ Medical School UPN Veteran, Jakarta
}

\begin{abstract}
Background: One of strategic goals of the Population and Family Planning Board for the 20152019 period is to increase active family planning participants using the Long-Term Contraception Method (MKJP). This method is emphasized by the government because it is the most effective way to reduce the birth rate. However, the data show that the interest in using MKJP by women of fertile age is still lower than that of using non-MKJP. This study aimed to determine the factors that influence the selection of MKJP among fertile aged women at public health center, Depok, West Java.

Subjects and Methods: This was an analytic observational study with a cross sectional design. The study was conducted at Sukmajaya public health center, Depok, West Java, Indonesia, from March to May 2019. A sample of 84 reproductive-age women was selected for this study. The dependent variable was choice of long term contraception. The independent variables were age, education, knowledge, income, employment status, number of children, and husband support. The data were collected by a questionnaire and analyzed using a multiple logistic regression.

Results: The choice of long-term contraceptive method increased with age $>35$ years $(\mathrm{OR}=$ 2.84; $95 \% \mathrm{CI}=0.86$ to 9.42$)$, high education $(\mathrm{OR}=3.40 ; 95 \% \mathrm{CI}=0.51$ to 22.67$)$, the number of children $\geq 3(\mathrm{OR}=1.25 ; 95 \% \mathrm{CI}=0.36$ to 4.38$)$, working mothers $(\mathrm{OR}=4.98 ; 95 \% \mathrm{CI}=1.06$ to 23.40), income $>$ Minimum Regional Wage $(\mathrm{OR}=0.21 ; 95 \% \mathrm{CI}=0.05$ to 0.85$)$, high knowledge $(\mathrm{OR}=5.01 ; 95 \% \mathrm{CI}=1.33$ to 18.85$)$, and strong husband support $(\mathrm{OR}=2.04,95 \% \mathrm{CI}=0.34$ to 11.44).

Conclusion: Factors that influence the choice of long term contraception methods are age, education, number of children, employment status, income, knowledge and support of husbands.
\end{abstract}

Keywords: long-term contraceptive, reproductive-age women

\section{Correspondence:}

Nancy Dalla Darsono. FK UPN Veteran Jakarta. South Jakarta. nancydallad@outlook.com. 08179986446 